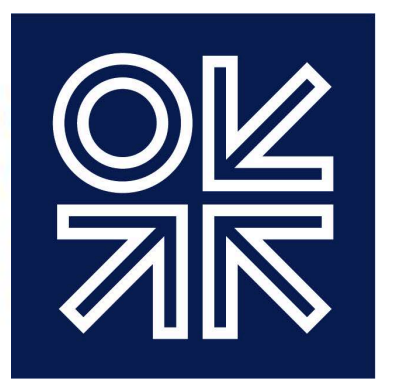

THE OXFORD

INSTITUTE

FOR ENERGY

STUDIES

September 2014

\title{
Prospects for Renewable Energy in GCC States:
}

Opportunities and the Need for Reform

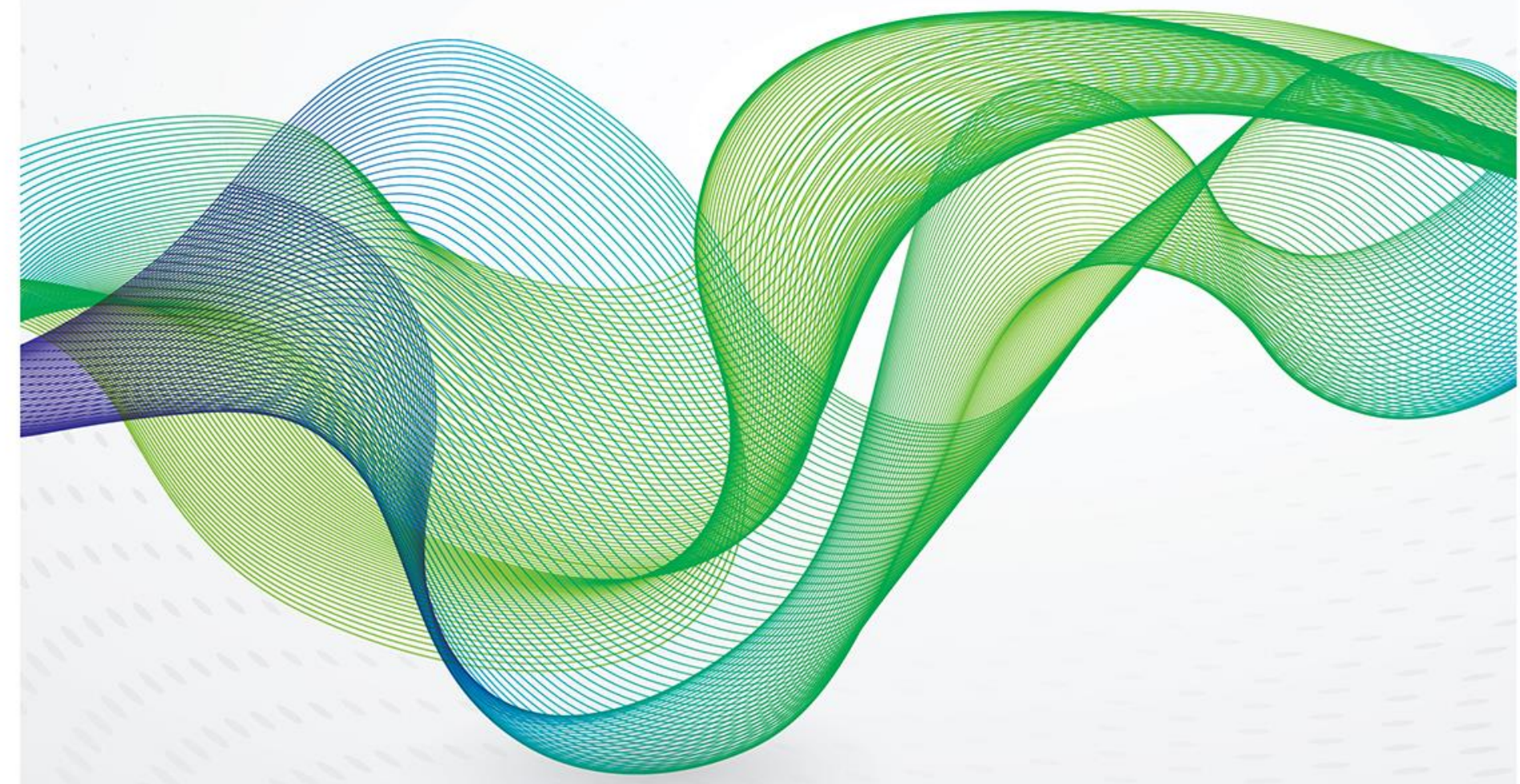


The contents of this paper are the authors' sole responsibility. They do not necessarily represent the views of the Oxford Institute for Energy Studies or any of its members.

Copyright $@ 2014$

Oxford Institute for Energy Studies

(Registered Charity, No. 286084)

This publication may be reproduced in part for educational or non-profit purposes without special permission from the copyright holder, provided acknowledgment of the source is made. No use of this publication may be made for resale or for any other commercial purpose whatsoever without prior permission in writing from the Oxford Institute for Energy Studies.

ISBN 978-1-78467-009-2 


\section{Acknowledgements}

The authors thank Bassam Fattouh, Ali Aissaoui, Osamah Alsayegh, and Malcolm Keay for their very helpful comments on earlier drafts of this paper. We are also very grateful to the Kuwait Fund for the Advancement of Sciences, which facilitated this research. We would also like to thank all participants who informed our research throughout a series of interviews in Kuwait City and London, including Faten Al-Attar, Reda Al Hasan, Mohammad Al Naki, and some other unnamed sources. We further thank Peter Kiernan and the Economist Intelligence Unit for sharing the data for Figure 1. All errors in this paper remain the authors' own.

Laura El Katiri is Research Fellow, OIES

Muna Husain is Assistant Professor at the Department of Economics, University of Kuwait 


\section{Contents}

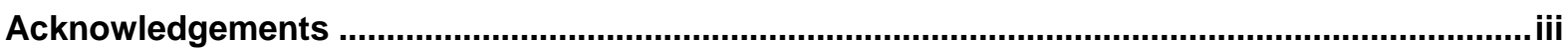

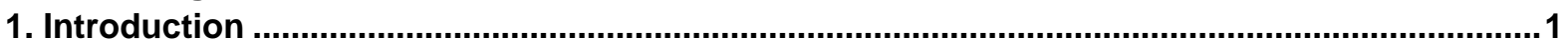

2. Opportunities for renewable energy in the GCC energy mix ................................................

Economic savings - the current situation compared to the 1980 s and 1990 s.................................

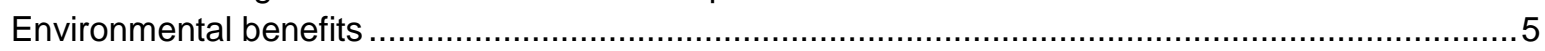

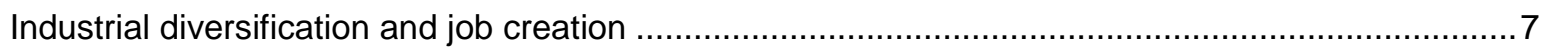

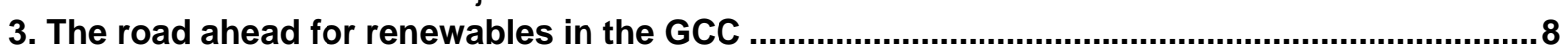

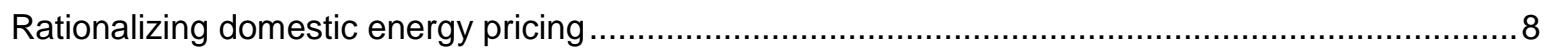

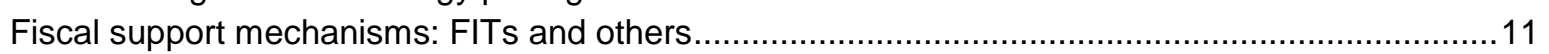

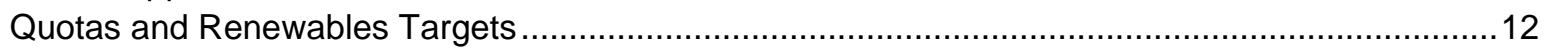

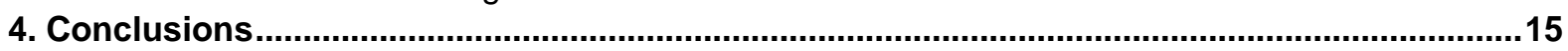

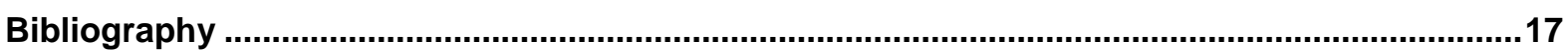

\section{Figures and tables}

Figure 1: Current and Projected Growth in Gross Domestic Energy Consumption, mtoe ....................1

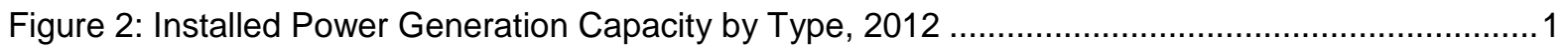

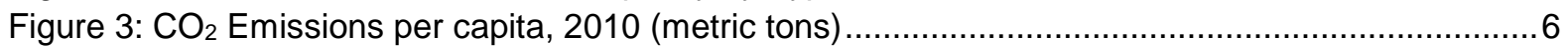

Figure 4: Average Retail Electricity Prices in Selected Countries (US $\mathrm{c} / \mathrm{kWh}), 2012 \ldots \ldots \ldots \ldots \ldots \ldots \ldots \ldots \ldots . . .9$

Figure 5: Retail price and estimated costs by fuel in Kuwait's power sector (US $\phi / k W h), 2012$............

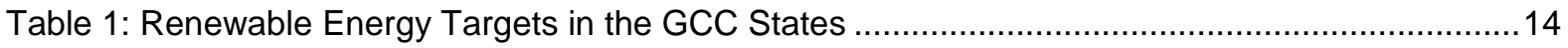



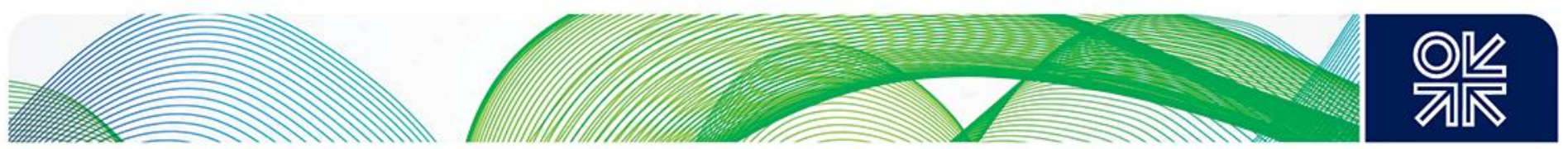

\section{Introduction}

The countries of the Gulf Cooperation Council (GCC) are situated in one of the most energy-rich regions in the world. Home to nearly a third of world oil and more than a fifth of global gas reserves most of which are concentrated between Saudi Arabia, the UAE, Kuwait, and Qatar - they remain one of the world's key centres of conventional oil and gas supply. ${ }^{1}$ Oil and natural gas resources have also fuelled the region's socio-economic development, having turned the GCC states within a mere few decades into some of the wealthiest nations (in per capita terms) in the world. ${ }^{2}$ The GCC states' unparalleled economic growth and industrial expansion, together with their rapidly rising living standards, have meanwhile left their mark on the region's domestic energy needs. Regional GCC energy consumption has risen by nearly six times since the 1980s - faster than in any other part of the world. ${ }^{3}$

It is this surge in domestic energy demand which, in the foreseeable future, is likely to pose one of the greatest policy challenges yet seen in the GCC. This is because domestic demand is intrinsically linked to the region's most important export product, hydrocarbon energy resources; these resources are primarily in the form of oil but in some cases (such as Qatar) of natural gas as well. With low-cost oil and natural gas accounting for virtually 100 per cent of the GCC states' domestic energy mix, their domestic energy demand is expected to continue rising at rates which are among the world's fastest over at least the next decade (Figures 1 and 2).

Figure 1: Current and Projected Growth in Gross Domestic Energy Consumption, mtoe

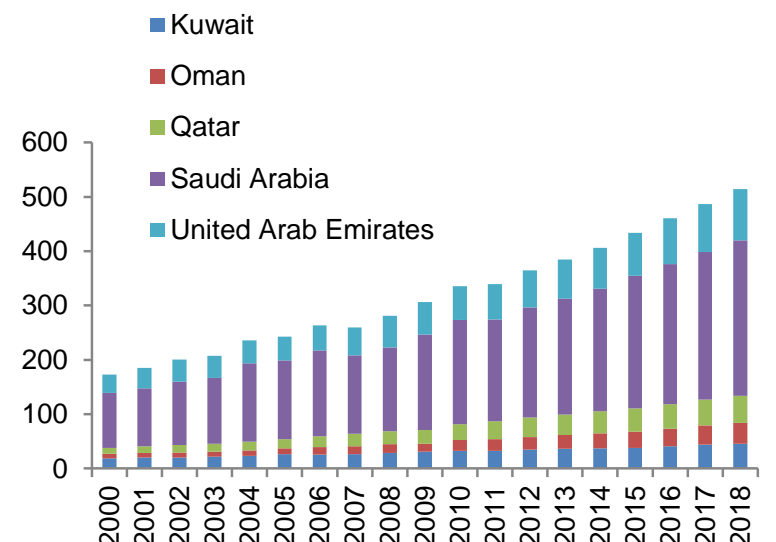

Source: Electricity Policy Research Group/Economist Intelligence Unit; 2014-18 estimates

\section{Figure 2: Installed Power Generation Capacity} by Type, 2012

-Oil $\square$ Diesel $\square$ Others $\square$ Open Gas $\backsim$ CCGT

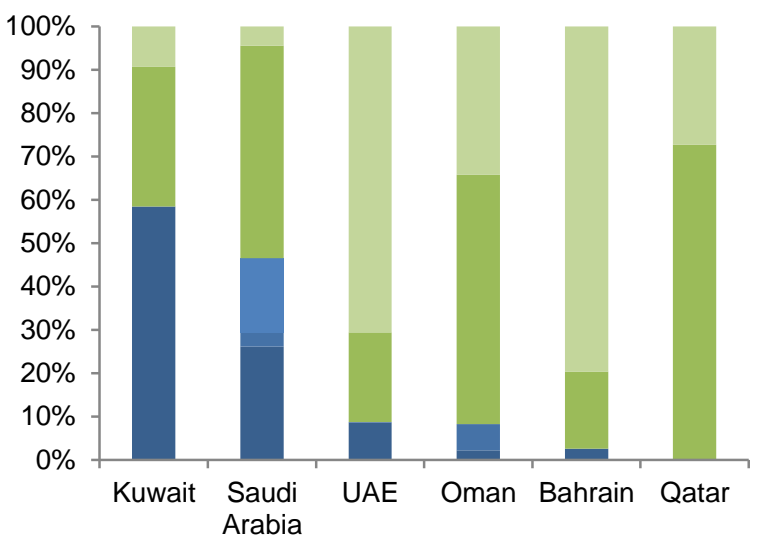

Source: AUPTDE (2013)

\footnotetext{
The GCC is made up of six member states Bahrain, Kuwait, Oman, Qatar, Saudi Arabia, and the United Arab Emirates (UAE). Shares and numbers based on EIA (2014) International Energy Statistics. Available at http://www.eia.gov/cfapps/ipdbproject/IEDIndex3.cfm.

${ }^{2}$ For a background, see Al Moneef (2006) The Contribution of the Oil Sector to Arab Economic Development, OFID Pamphlet Series No. 34, Vienna: OPEC Fund for International Development; Fattouh, B. and El-Katiri, L. (2012) 'Energy and Arab Economic Development' Arab Human Development Report Research Paper Series, United Nations Development Programme. Available at www.arab-hdr.org/publications/other/ahdrps/ENGFattouhKatiriV2.pdf (retrieved January 2014).

${ }^{3}$ Authors' calculations based on EIA (2014), simple growth between 1980 and 2010. According to this data only China, taken on its own, can rival this growth in energy consumption.
} 
Remaining dependent for up to 90 per cent of total government revenues ${ }^{4}$ on the export of their valuable oil and natural gas resources, the GCC states' rising domestic oil and gas demand will present them with a significant fiscal and macroeconomic problem if current demand and supply policies remain unchanged.

In this paper, we look at one potential policy response in the context of the GCC states' rising energy needs: the promotion of alternative energy sources, specifically renewables. The potential for renewable energy, particularly solar power, in the GCC is undoubtedly vast, given the Arabian Peninsula's highly suitable climatic conditions and the match (typical for the region) between peak sun hours and electricity demand. ${ }^{5}$ Utility generation for electricity and, in the GCC widely, for desalinated water accounts for between one and two thirds of total primary energy consumption, suggesting tremendous potential for reform in the utility sector, which would affect GCC energy markets at large. ${ }^{6}$ However, experience suggests that the potential for renewable energy in the GCC is not so much limited by resources as by economics. Domestic energy and utility market structures - including the vexed question of domestic energy pricing in the region - remain one of the most important hurdles to the systematic growth of renewables in the GCC region; this issue ties supply-sided policy success such as the promotion of renewables to further reforms on the demand side, particularly in utility pricing. We use the case of Kuwait below to examine those factors that have inhibited, and may continue to act as barriers to, the deployment of renewables in the GCC region. The rest of the paper is organized as follows. Section 2 discusses opportunities for renewable energy in the GCC. Section 3 examines policies to support renewable energy in the GCC. Section 4 concludes.

\section{Opportunities for renewable energy in the GCC energy mix}

The policy focus on renewables in the Gulf has been a recent one. For many decades, oil and natural gas were held as the main developmental ingredient, not only through their role as a primary source of income for the GCC states, but also as a low-cost fuel to be used in domestic energy-intensive industries such as petrochemicals, steel, and aluminium production, and also in power generation. ${ }^{7}$ Renewable energy technology was not a policy focus until well into the $1990 \mathrm{~s}$, primarily due to the lack of cost-competitiveness with the Gulf's low-cost oil and gas - with which renewable technologies would have competed. The Kuwait Institute for Scientific Research (KISR) was founded in 1967 as one of the Gulf states' first research institutions tasked with studying the potential application, and assessing the economic benefits, of alternative energy options such as renewable energy for Kuwait and the GCC. The centre studied both solar and wind technology in the context of Kuwait, using experimental projects and economic modelling exercises; this defies suggestions by today's media landscape that the GCC states were just not that interested in renewables during this period of time.

Initial studies during the late 1970s and the 1980s were conclusive; when KISR's original research team discontinued its studies in 1986, they concluded that, based on cost, useful energy production from solar technologies 'was not cost-effective' and that it did not 'serve the strategic interests of the

\footnotetext{
Fattouh and El-Katiri (2012), 13, based on data by the Arab Monetary Fund.

${ }^{5}$ Electricity demand in the Gulf region follows distinctively different patterns throughout the year. Unlike in Europe, electricity demand suddenly increases during the summer months, when temperatures are at their highest and air conditioner use surges. We discuss this in more detail below. For resource potential, see e.g. DLR (2005); BNEF (2011); for specific studies of Kuwait, see e.g. Al-Enezi et al. (2011); Ramadhan and Naseeb (2011); Al-Nassar et al. (2005); Alotaibi (2011).

${ }^{6}$ Authors' calculations based on IEA, with shares from 2011. The lowest share of utility generation in total primary energy $(P E)$ consumption was found in Qatar, with 26\%; the highest share was found in Kuwait, with 74\% of gross PE consumption.

${ }^{7}$ E.g. Al-Moneef (2006); Crystal, J. (1995) Oil and Politics in the Gulf: Rulers and Merchants in Kuwait and Qatar. Cambridge: Cambridge University Press. For Kuwait, see: Al-Sabah, Y. S. F. (1980). The Oil Economy of Kuwait. London: Kegan Paul International; Al-Yahya, M. A. (1993) Kuwait: Fall and Rebirth. London: Kegan Paul International.
} 
country'. ${ }^{8}$ The high cost of concentrating solar power (CSP), photovoltaic (PV), and wind technologies at the time (in comparison with current costs) played one major role in these results - the other major factor having been the comparative price of conventional fuel supplied by Kuwait's state-owned company, Kuwait Petroleum Corporation (KPC) through oil, and later on natural gas, from the country's own production. In studies taking place during the $1980 \mathrm{~s}$, oil was priced at around $\$ 6 / \mathrm{bl}$, this moved up to around $\$ 20 / \mathrm{bl}$ during the $1990 \mathrm{~s} .{ }^{9}$ These prices for oil reflected the very moderate marginal cost of oil production in Kuwait (and in other GCC states) as well as the significantly lower world market prices for oil in real terms.

\section{Economic savings - the current situation compared to the 1980 s and 1990 s}

Several decades after the initial oil boom in the 1960s and 1970s that cemented the Gulf states' reliance on hydrocarbon-fuelled power and desalination technologies, the region's focus has begun to shift back towards a more diversified energy portfolio for its domestic economies - once again for primarily economic reasons. Technology costs for energy production from CSP, PV, and wind have fallen significantly since the 1990s and 2000s, with further potential for cost reductions. ${ }^{10}$ At the same time, world market prices for oil have risen significantly - as has the cost of production from many maturing oil fields and the cost of production of natural gas - and today it is in short supply in a number of GCC nations, including Kuwait.

The economic case is most obviously argued in situations where renewable energy alternatives replace oil-fired power generation. Accounting for over half of Kuwait's operating power generation capacity, oil has become an expensive fuel to power the country's utility sector. At a world market price that has been in the range of $\$ 90-110 / \mathrm{bl}$ since the latter half of the 2000 s, Kuwait loses out on significant export revenue for each barrel burnt in domestic power generation, where it is priced at or below the long-run marginal cost (LRMC) of production. The opportunity cost of the use of oil for domestic power generation is actual value lost to the economy; it is revenue that could have fed into social welfare systems or future generations' savings funds, or into the development of cleaner, more environmentally friendly energy solutions which would have considerably improved the quality of life for Kuwait's citizens.

A number of studies have examined the potential cost advantage of renewable energy - mostly solar CSP and PV power given the important potential for solar power in the GCC - in line with higher and more realistic oil price assumptions based on the value of crude oil on international markets. While most of these studies are not country-specific, they give a rough idea of the changing economics of renewables in the Middle East region. A 2011 Bloomberg study found that when the falling costs of solar PV technology were taken into account, solar power could be a cost-effective solution for Middle East utilities at an oil price of $\$ 80 / \mathrm{bl}$ or above. ${ }^{11} \mathrm{~A} 2012$ ESIA study, which looked at the potential for solar PV in the Middle East and North Africa, reaffirmed these results. ${ }^{12}$ For Kuwait, several studies confirm that solar PV could be cost-competitive with oil-fired power generation at a crude oil price of

\footnotetext{
${ }^{8}$ Kuwait Institute for Scientific Research (KISR, 2008) Scientific Report 2006-2008. p.viii, as quoted by Bachellerie, I.J. (2012) Renewable Energy in the GCC Countries: Resources, Potential and Prospects. Gulf Research Centre, 61

${ }^{9}$ Personal interviews by the authors, May 2014; Ghoneim et al (2002).

${ }^{10}$ For background, and for a comparison of a number of institutions' cost projections for different renewable technologies, see REN21/ISEP (2013) Renewables Global Futures Report (Paris: REN21), 52-60; on solar power, see Brown, A., Mueller, S., and Dobrotkova, Z. (2011). 'Renewable Energy Markets and Prospects by Technology', Information Paper, International Energy Agency, Paris: IEA, 34-48.

${ }^{11}$ BNEF (2011).

${ }^{12}$ Mills (2012) Sunrise in the Desert. Solar Becomes Commercially Viable in the MENA. Emirates Solar Industry Association (ESIA), 8.
} 

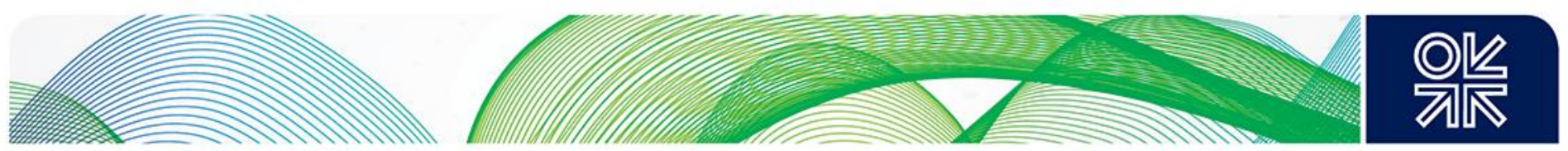

$\$ 100 / \mathrm{bl},{ }^{13}$ using a very conservative cost figure for PV technology; ${ }^{14}$ this implies substantial scope for $\mathrm{PV}$ cost-competitiveness at a lower price range for oil.

The cost-competitiveness of solar power versus conventional fuels is less obvious in the case of natural gas, however, and depends heavily on the cost assumptions made for the competing gas. Under ESIA's estimates, solar power is cheaper than open-cycle gas-fired power generation providing peak load at gas prices above $\$ 5 / \mathrm{MMBtu}$ (equivalent to oil at around $\$ 30 /$ barrel), while it requires a price of $\$ 17 / \mathrm{MMBtu}$ (around current prices for imported LNG) for solar to be competitive with baseload combined-cycle power (CCGT). ${ }^{15}$ These estimates are based on a typical cost of US $\$ 15.4 / \mathrm{kWh}$ for PV power at an installed capital cost of $\$ 2.50 / \mathrm{W} .{ }^{16}$ With a trend towards CCGT in domestic power generation in the Gulf and beyond, the most relevant gas price to consider is hence the upper-price value of $\$ 17 / \mathrm{MMBtu}$ (this is around current LNG import contract levels under conventional supply contracts that link the price of gas to the currently high price of oil on world markets). KISR studies confirm that in the case of Kuwait, current industry gas price assumptions do not render solar PV cost-competitive with existing CCGT plants. ${ }^{17}$

Hence for large, self-sufficient gas producers such as Qatar and Saudi Arabia, solar and other potential renewables may not yet offer a cost-competitive solution when competing with natural gas, though potentially such technologies would be competitive in replacing oil-fired power generation. But even in the case of gas-fired power generation, the story is not as straightforward as a simple cost comparison might suggest. Kuwait, along with its GCC neighbour the United Arab Emirates (UAE), is already an importer of high-cost LNG, a prospect which is also likely to be faced by Bahrain within the next five years. ${ }^{18}$ As Kuwait faces the prospects of rising LNG imports from international markets, the commercial attractiveness of PV (and potentially of other alternative energy sources to high-cost LNG) is likely to increase over time. This is reflected in ESIA's report, which concludes that:

... as imported fuel (gas or oil) prices increase, solar power will increasingly become a viable part of the [Middle East's] generation mix. ${ }^{19}$

Moreover in Saudi Arabia and Kuwait, summer shortages of natural gas - in spite of annually increasing import volumes in Kuwait - lead to the regular burning of crude oil in place of insufficient gas supplies. Saudi Arabia itself has variously signalled that it does not intend to import natural gas in the foreseeable future. This is a policy which may also be seen in the context of the Kingdom's exceptions under its WTO membership for the pricing of feedstock gas for its petrochemicals products, where gas imports might considerably complicate the pricing of domestically produced gas to the Kingdom's export industries..$^{20}$ In both cases, solar power could contribute to reduce the daily load to be supplied by conventional thermal oil- and gas-fired plants, reducing the burning of valuable crude. In Kuwait, these savings could be substantial, as studies have shown that a simple $1000 \mathrm{MW}$

\footnotetext{
${ }^{13}$ Ramadhan and Naseeb (2011); Ramadhan, Hussain and Behbehani (2013), 'The Prospect of Solar Energy in the Development of Power Stations in the State of Kuwait' Journal of Renewable Energy, Volume 2013.

${ }^{14}$ The authors use a cost estimate for photovoltaic power of between US $\$ 19 / \mathrm{kWh}$ and US $\$ 28 / \mathrm{kWh}$. Other cost estimates place this cost at between US\$12.6 and US\$18.1/KWh (Mills, 2012).

${ }^{15}$ Mills $(2012,8)$.

${ }^{16}$ Mills $(2012,8)$

${ }^{17}$ Ramadhan, M., Hussain, A. and Behbehani, D. $(2013,3)$.

${ }^{18}$ EIA (2013) Bahrain Country Analysis Brief. Accessed from www.eia.gov/countries/country-data.cfm?fips=ba (accessed July 2014); see also El-Katiri (2013) 'Energy Sustainability in the Gulf States: The Why and the How', OIES Research Paper, MEP 4, fn54, 14

${ }^{19}$ Mills $(2012,8)$.

${ }^{20}$ For a recent document on the Kingdom's accession policies to the WTO, see World Trade Organization (2011) Trade Policy Review. Report by the Kingdom of Saudi Arabia. WT/TPR/G/256, downloaded from

www.wto.org/english/tratop e/tpr e/g256 e.doc (accessed July 2014); see also Hammerl, L. (2007) ‘Saudi Arabia's Accession to the WTI: Opportunities and Predicaments', Unpublished B.A. dissertation, University of Exeter.
} 

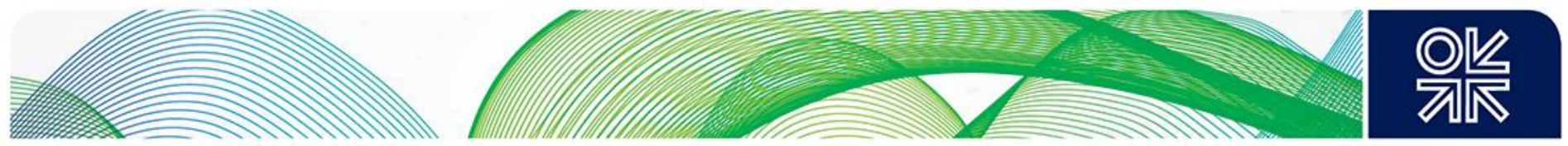

fixed PV system could reduce daily peak demand by about 20 per cent, ${ }^{21}$ and total annual electricity consumption by approximately 15 per cent. ${ }^{22}$ Other estimates suggest these figures are exaggerated and that actual reductions of peak demand with 1000 MW PV would merely amount to some 3 per cent - a small amount relative to the cost of installing PV plants in Kuwait. ${ }^{23}$

In the case of oil, the argument suggests that significant savings can be made. Moreover, the prospects of rising energy and electricity needs in the GCC suggests that in the absence of alternative supply options, oil and natural gas produced domestically will increasingly be diverted away from the main revenue-generating export markets, towards their use for domestic energy generation. Crude oil consumption by the power sector alone has reached close to $100,000 \mathrm{~b} / \mathrm{d}$ in Kuwait and up to $750,000 \mathrm{~b} / \mathrm{d}$ in Saudi Arabia during the summer months; ${ }^{24}$ while by 2011 (the time of the latest figures available) Kuwait's total primary energy consumption amounted to around 308,000 boe, a figure which has probably increased and which represents around a tenth of the country's total oil production. ${ }^{25}$ At the same time, Saudi Arabia is already the world's sixth and seventh largest consumer of oil and gas. In per capita terms, the GCC economies of Kuwait, the UAE, Bahrain, and Qatar are amongst the highest consumers of primary energy and electricity and are expected to grow further in the coming years. ${ }^{26} \mathrm{~A}$ Kuwaiti observer described prospects for Kuwait, suggesting:

The total energy consumption in [Kuwait] has increased more than three-fold, from an equivalent of 0.17 to $0.54 \mathrm{Mb} / \mathrm{d}$ at an average annual rate of $8 \%$ over the period of 1992-2007. With this increase in consumption, and at the current production rate, all of the produced energy will be consumed locally by $2027 .^{27}$

Once again, alternative sources of supply have the potential to assume a highly strategic role in securing export volumes, and thereby the fiscal stability of Kuwait and the other GCC nations.

\section{Environmental benefits}

In addition to their potential economic role, renewable energy technologies can also offer additional benefits to the GCC states as alternatives to oil and natural gas, particularly in the sphere of environmental policy. Environmental considerations have not been a traditional policy concern in the GCC region; this approach includes the region's traditional shying-away from the debate around climate change. ${ }^{28}$ There is, however, good reason to consider the more harmful effects of a country's reliance on fossil fuel-based power generation on its economy, and to consider the potential benefits which alternative sources have to offer, over and above their economic benefits. Kuwait City, for instance, featured in a 2011 WHO study as the world's tenth most polluted city based on reported numbers from 2003, since when urban air pollution is expected to have climbed considerably, in line with Kuwait's rapidly rising energy consumption rates. ${ }^{29}$ Similarly, Qatar was most recently reported to be facing fine-particle concentration levels six times above permissible limits - a substantial health

\footnotetext{
${ }^{21}$ Al-Hasan, Y.A. et al. (2004); Alotaibi (2011)

22 Alotaibi (2011); Ghaddar et al., (1997).

23 The authors thank Osamah Alsayegh for these insights.

${ }^{24}$ Kuwait, like Saudi Arabia, burns large volumes of crude oil in summer to overcome temporary shortages in natural gas supplies. E.g. see 'Kuwaiti oil refineries vulnerable to more power problems', Reuters, 16 February 2014; 'Kuwait Ponders Long-Term Power Fuel Supply Options: MEES Analysis', MEES, 56:24, 14 June 2013; 'Kuwait Burns Crude, Turns To

Renewables, To Meet Fuel Challenge' MEES, 55:12, 19 March 2012.

25 IEA data, available at www.iea.org/sankey/\#?c=Kuwait\&s=Balance (accessed July 2014).

${ }^{26}$ Kuwait and the GCC economies, together with other parts of the Middle East, are expected to contribute alongside Asian economies the majority of the world's growth in energy consumption in the period up to 2040 in a variety of forecasts. E.g International Energy Agency (2014) World Energy Outlook 2014. Paris Cedeux: International Energy Agency.

${ }^{27}$ Alotaibi (2011, 638); see also Darwish et al (2008).

${ }^{28}$ Russell, J.A. (2011) 'The Persian Gulf: Bahrain, Iran, Iraq, Kuwait, Qatar, Saudi Arabia, the United Arab Emirates, and Oman', in Daniel Moran (ed.), Climate Change \& National Security, Washington D.C.: Georgetown University Press, 163-76; Luomi, M. (2011) 'Gulf of Interest: Why Oil Still Dominates Middle Eastern Climate Politics', Journal of Arabian Studies, 1:2, 249-266; Patlitzianas et al. (2006).

29 'Global air pollution: what is the most polluted country and city in the world?' The Guardian, 26 September 2011
} 

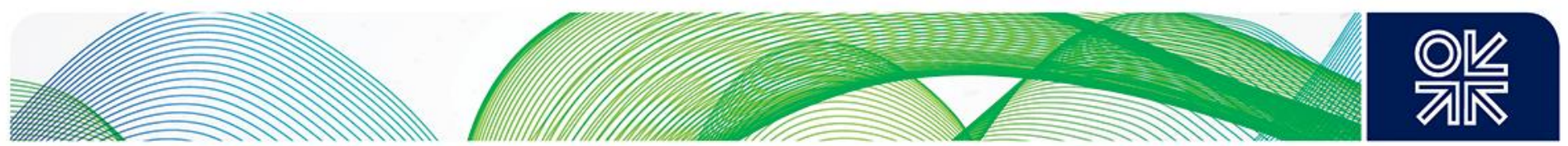

risk for adults and children. ${ }^{30}$ It is perhaps unsurprising for residents of the Gulf's most populated cities that Kuwait, the UAE, and Saudi Arabia already rank amongst the highest-polluted countries, on the basis of country-wide mean pollution levels for fine particulate matter - notably ahead of countries such as China and India, whose urban pollution problems are met by significantly more media attention. ${ }^{31}$ These findings also reflect similar suggestions in previous research in Kuwait, suggesting that the problem is known, but has met with little political attention. ${ }^{32}$

With some of the world's highest per capita consumption rates of primary energy and electricity Kuwait, together with some of its smaller GCC neighbours such as Qatar, the UAE, and Bahrain, also features some of the world's highest $\mathrm{CO}_{2}$ emissions in per capita terms (Figure 3). While the relative size of their economies still renders their emissions in volume terms significantly smaller than those of larger economies such as India, China, Europe, and North America, all the GCC states are signatories to the United Nations Framework Convention on Climate Change (UNFCCC) and have ratified the UN's Kyoto Climate Change Protocol since 2005, having therefore committed to reducing their carbon footprint. ${ }^{33}$ Some GCC states - including Kuwait and the UAE - have subsequently looked very seriously into the area of carbon capture and storage (CCS), a logical route for oil and gas producers yet one fraught by various cost-related challenges, and one which is largely still to prove itself. ${ }^{34}$ The UAE in particular have also designed and submitted several renewables projects under the UNFCCC Clean Development Mechanism programme (UNFCCCCDM), with the aim of complying better with Kyoto protocol provisions. ${ }^{35}$

Figure 3: $\mathrm{CO}_{2}$ Emissions per capita, 2010 (metric tons)

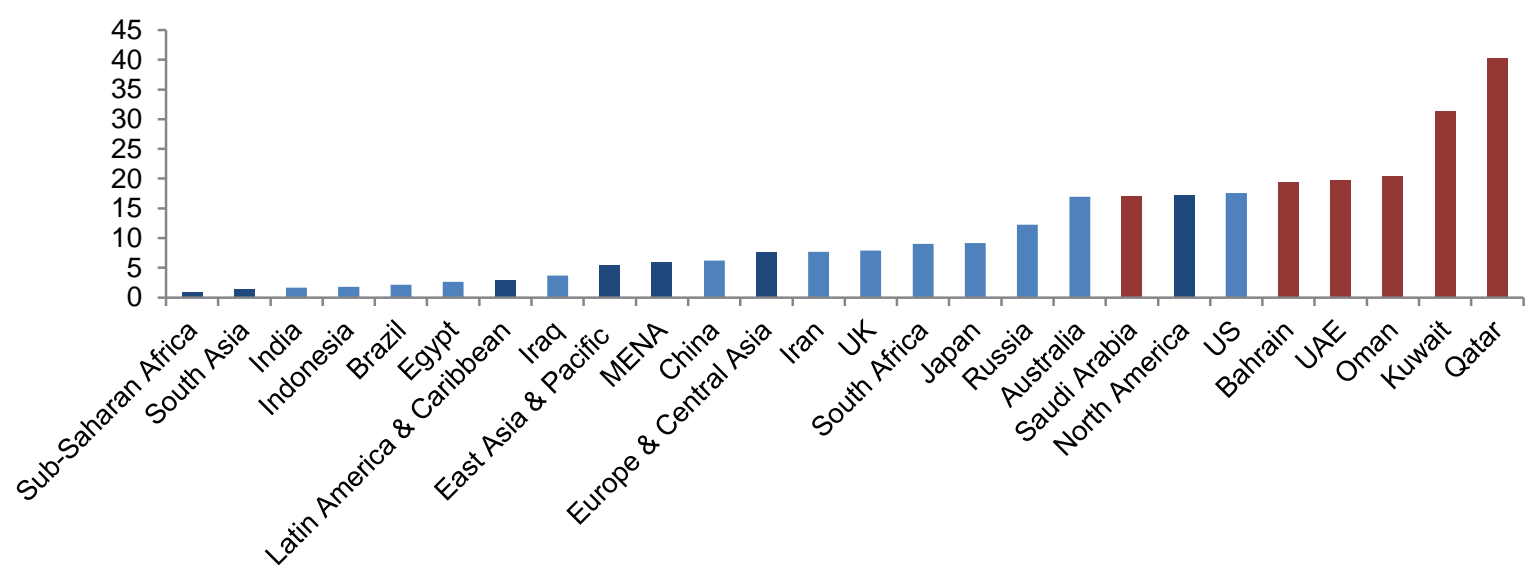

Source: World Bank (2014)

\footnotetext{
${ }^{30}$ Astorri, F. (2013) 'Qatar air pollution six times over limit - study’ ArabianBusiness.com, 22 January 2013.

${ }^{31}$ World Health Organization (2014) Ambient Air Pollution Database, May 2014. Available at www.who.int/phe/health topics/outdoorair/databases/cities/en/.

${ }_{32}$ Al-Nassar et al. (2005); see also Alotaibi (2011); Darwish et al. (2008); Al-Harbi, M. (2013). A report by the UN ESCWA and the Arab League laments this lack of attention paid to air pollution generally in the Arab region. UNEP (2007) Air Quality and Atmospheric Pollution In the Arab Region, Economic and Social Commission for Western Asia/League of Arab States, available at www.un.org/esa/sustdev/csd/csd14/escwaRIM bp1.pdf, 6.

${ }^{33}$ Bachellerie, I.J. (2013) 'Sustainability and Competitiveness: A Pragmatic Approach to Solar Energy Transition in the GCC Countries', GRC Gulf Paper, Gulf Research Centre, 7; Luomi, M. (2014) 'Mainstreaming Climate Policy in the Gulf Cooperation Council States' OIES Paper, MEP 7, Oxford Institute for Energy Studies.

${ }^{34}$ Bachellerie (2013), 7; Mills, R. (2014) 'Climate Change and CCS in the GCC', Oxford Energy Forum, 96, May 2014, 38-41; Meltzer, J., Hultman, N., and Langley, C. (2014) Low-Carbon Energy Transitions in Qatar and the Gulf Cooperation Council Region, Washington D.C.: The Brookings Institution. See also Reiche, D. (2010) 'Renewable Energy Policies in the Gulf countries: A case study of the carbon-neutral "Masdar City" in Abu Dhabi', Energy Policy, 38 (2010) 378-82.

${ }^{35}$ Bachellerie, I.J. (2013) 'Sustainability and Competitiveness: A Pragmatic Approach to Solar Energy Transition in the GCC Countries' GRC Gulf Paper, Gulf Research Centre, 7.
} 
Renewable energy technologies could play an important role in addressing both issues - air pollution and carbon emissions - in the GCC. In particular, revising the GCC states' policy take on climate change may provide them with an important policy argument in favour of both saving energy at the consumer level and justifying investment into (potentially still more expensive) renewable energy technology as a long-term solution to their surging energy demand and hence their pollution and emissions levels. A recent paper from the Oxford Institute for Energy Studies raises, in this context, the potential for the economies of the GCC to 'mainstream' their climate change policies - a step which could become a milestone in the reorientation of the region's energy profile and of its citizens' expectations for the state's role in offering them a sustainable energy future. ${ }^{36}$

\section{Industrial diversification and job creation}

Renewable energy deployment, if done sensibly and adapted to the local context, can also entail significant backward and forward linkages with the economy at large, offering the potential for related industry-creation as well as the creation of new, 'green' jobs.37 The range of jobs created notably includes engineering and technology specialists; this corresponds well with the type of white-collar jobs the GCC states are keen to provide for their young and increasingly well-educated citizens. The creation of small innovative renewable technology industries, which could also include R\&D, could hence have the potential of fitting well with the GCC states' existing policy objectives of creating more local jobs, while also corresponding to the region's existing status as a hub for multiple energy technologies. Unlike in the case of nuclear technology, renewables also offer a technology option with no political controversy attached, while the technology is easily transferrable and, in the case of solar and wind power, mature.38 Niche technologies such as geothermal and wave energy could offer interested GCC states further areas for research and hence for job creation. The UNDP highlights that:

... compared to fossil fuel power plants, renewable energy generates more jobs per unit of installed capacity, per unit of power generated and per dollar invested. ${ }^{39}$

Among the GCC states, the UAE seem to have understood this potential already, having invested significantly into highly visible projects such as Shams-1 (the world's largest CSP plant) and Masdar City, in addition to having secured the position of hosting the International Renewable Energy Agency (IRENA). ${ }^{40}$ While the majority of employees in these activities have up to now been expatriates, there is potential to replace these people with local expertise over the long run. This, however, depends on demand for relevant skills being created now, incentivizing young students to consider a career in such areas as renewable and alternative energy research (including nuclear power), and on sustainable development in such areas as engineering and architecture. Such commitment reflects the GCC states' favourable fiscal position which enables them to invest in new renewable energy projects - in a more significant way than many other emerging economies - and also highlights the dual nature such projects hold, not only in the generation of employment and local expertise, but also in sending important positive signals to potential investors.

Caution, of course, has to be applied to expectations over a potential 'miracle' industry, for 'green' jobs will need to be carefully crafted in order to support the GCC states' interest in creating productive industries rather than artificial, unproductive sinks. The GCC economies, including Kuwait, will need to invest significantly in the upgrading of local skills, in order to support more R\&D in renewables, if it

\footnotetext{
${ }^{36}$ Luomi, M. (2014) 'Mainstreaming Climate Policies in the Gulf Cooperation Council States', OIES Research Paper MEP 7, Oxford Institute for Energy Studies.

${ }^{37}$ OECD (2013, 38). See also ILO (2008), El-Husseini et al. (2009); IEA (2011, 69); OECD (2011).

${ }^{38}$ El-Katiri (2014); Patlitzianas, K.D., Doukas, H., and Psarras, J. (2006). 'Enhancing renewable energy in the Arab States of the Gulf: Constraints \& efforts', Energy Policy, 34 3719-26.

${ }^{39}$ UNEP (2008). See also Lund (2009).

40 'UAE 3rd in concentrated solar power capacity', Khaleej Times, 4 June 2014; Reiche (2010); Griffiths, S. (2014) 'Masdar City: "City of Possibilities"', Oxford Energy Forum, 96, May 2014, 18-21.
} 

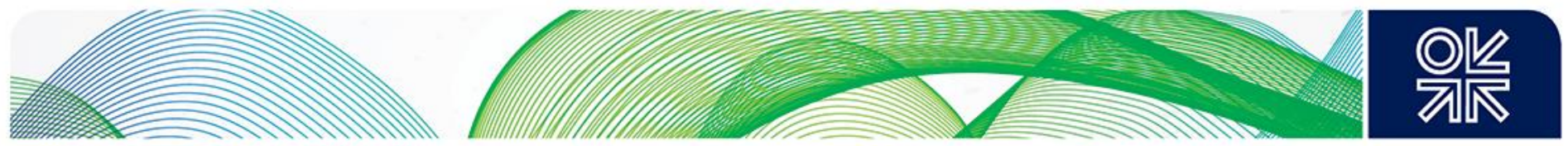

wants this sector to be locally-driven rather than based on yet more expatriate labour. ${ }^{41}$ If incentives in current labour markets across the GCC for nationals to engage in value- and performance-driven activities are missing, this means that any renewables-driven economic activity can realistically only contribute towards reducing economic deadweight loss, while reducing costs over the long term through a local industry learning curve - if local markets set the right incentives for labour. ${ }^{42}$

\section{The road ahead for renewables in the GCC}

The introduction of alternative sources of energy into an existing energy market is never an easy task, as has been shown variously by the many different approaches found in European and North American markets for renewable energy. 43 In the GCC states, the debate around renewables has furthermore been led in parallel to plans for nuclear power in Saudi Arabia and the UAE, with other member states - Kuwait, Qatar, and Bahrain - having entertained their own plans in the past.44 Despite the frequently invoked claims of competition between nuclear and renewable energy, the two technologies appear to be largely complementary, but would require similar domestic market adjustments. 45 While progress in the deployment of renewables markedly differs across the Gulf states, renewables face largely similar barriers to their systematic deployment in the region - beyond government-led initiatives and popular prestige projects, which include Abu Dhabi's highly symbolic projects: Masdar City and Shams-1, the world's largest CSP power plant.

\section{Rationalizing domestic energy pricing}

Energy pricing remains one of the most important factors influencing the deployment of different energy technologies over the short and long term. In the GCC states, domestic energy prices have been subject to decades of price controls under un-liberalized markets in which the state utility has been the sole provider of water and electricity. In the Gulf states, the inflow of oil revenues, primarily since the 1960s, has since been coupled to what some see as an informal 'social contract' between citizens and their governments: the government collects oil revenues and re-channels the revenues back to its citizens in ways which include indirect transfers in the form of low-cost fuel, electricity, and water. In countries such as Qatar, up until recently, every citizen enjoyed an allowance of free water and of electricity up to a certain volume of consumption. Even in the absence of benevolent state subsidies for electricity, utility provision in the GCC states has been cheap: domestically produced oil has been provided at a historical cost range of a few dollars per barrel, natural gas at a range of $\$ 0.75-1.50 / \mathrm{MMBtu}$. These prices reflected historical production costs that made GCC energy provision some of the lowest-priced energy in the world (see Figure 4 for electricity).

Kuwait's flat fee of 2fils/kWh (<US $\$ 1 / \mathrm{kWh}$ ) for residential electricity users, and $1 \mathrm{fils} / \mathrm{kWh}$ for industrial users has been in place unchanged since the 1960s; this means that effective electricity charges have decreased in real terms even as demand has surged at very high rates. ${ }^{46}$ Being an important contributory factor behind the GCC states' rapid energy consumption growth over the past decades, these low, government-administered prices have been a most formidable investment barrier for

\footnotetext{
${ }^{41}$ IEA $(2011,69) ;$ OECD (2011)

${ }^{42}$ El-Katiri, L. (2014) 'A Roadmap for Renewable Energy in the Middle East and North Africa' OIES Paper, MEP 6, Oxford Institute for Energy Studies, 21-3.

${ }^{43}$ For an overview, see REN21/ISEP (2013) Global Renewables Futures Report 2013. Paris: REN21, 44-51.

${ }^{44}$ Luciani, G. (2012); El-Katiri, L. (2012) 'The GCC and the Nuclear Question', Oxford Energy Comment, Oxford Institute for Energy Studies.

${ }^{45}$ Nuclear power provides base load capacity whereas renewable power, specifically solar PV, would be most suitable to supply peak load. For a more detailed discussion, see Marktanner, M. and Salman, L. (2011) 'Economic and geopolitical dimensions of renewable vs. nuclear energy in North Africa', Energy Policy, 39 (2011) 4479-89.

${ }^{46}$ Ramadhan, Hussain and Behbehani $(2013,2)$; Osamah Alsayegh, Kuwait Institute for Scientific Research.
} 
domestic utilities - failing to run even at an estimated total production, transmission, and distribution cost of $40 \mathrm{fils} / \mathrm{kWh}$ (US\$12/kWh). ${ }^{47}$

Figure 4: Average Retail Electricity Prices in Selected Countries (USc/kWh), 2012

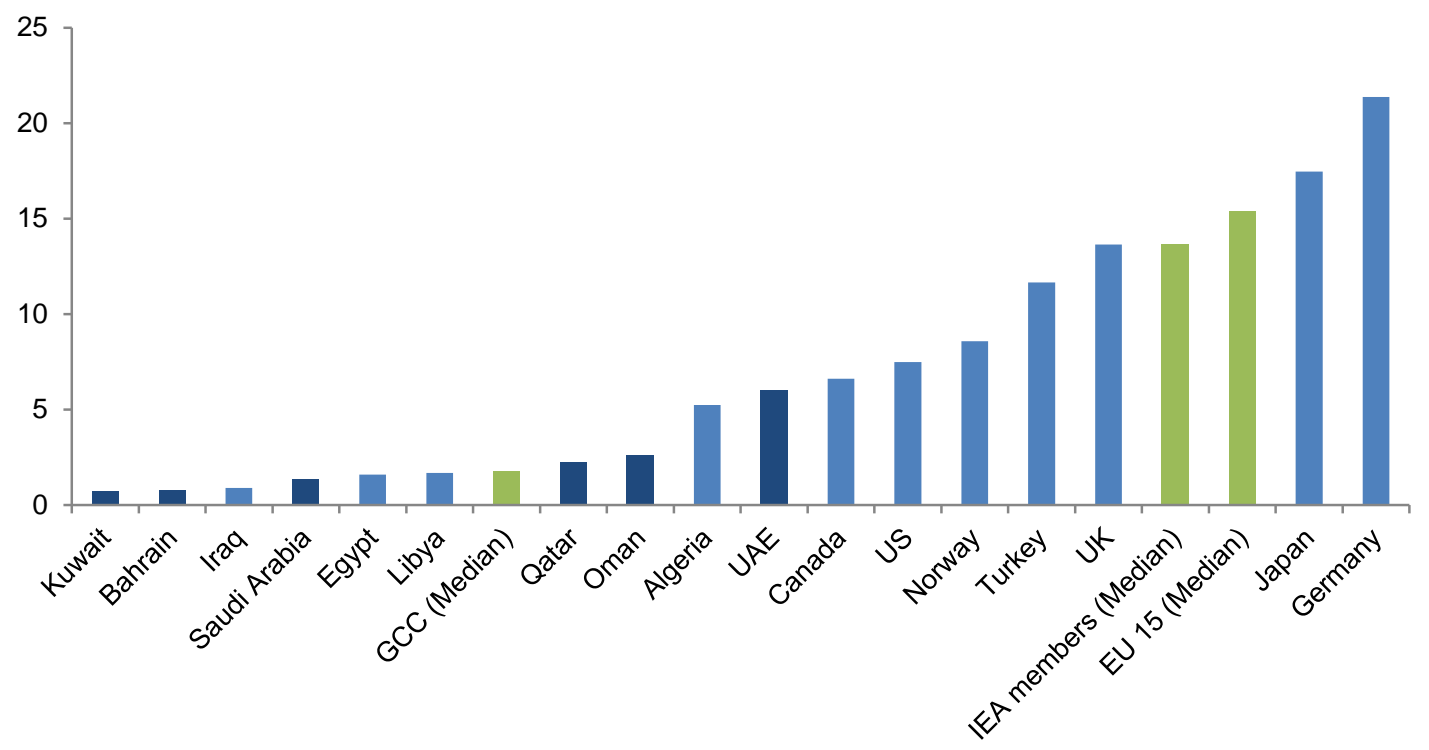

Source: AUPTDE (2013), IEA

This has arguably also been a problem for the implementation of Kuwait's legal changes in 2008, which required all generation projects greater than $500 \mathrm{MW}$ to be implemented by Public-Private Partnerships (PPPs).$^{48} \mathrm{~A}$ lack of profits has been one major factor that explains lagging investment in new generation capacity for over ten years; this has led to recurring power shortages in Kuwait during the peak summer period for several years since the late 2000s. ${ }^{49}$ Figure 5 illustrates the wide gap between production costs for different fuel technologies and actual tariffs in the case of Kuwait.

Figure 5: Retail price and estimated costs by fuel in Kuwait's power sector (US $\phi / k W h), 2012$

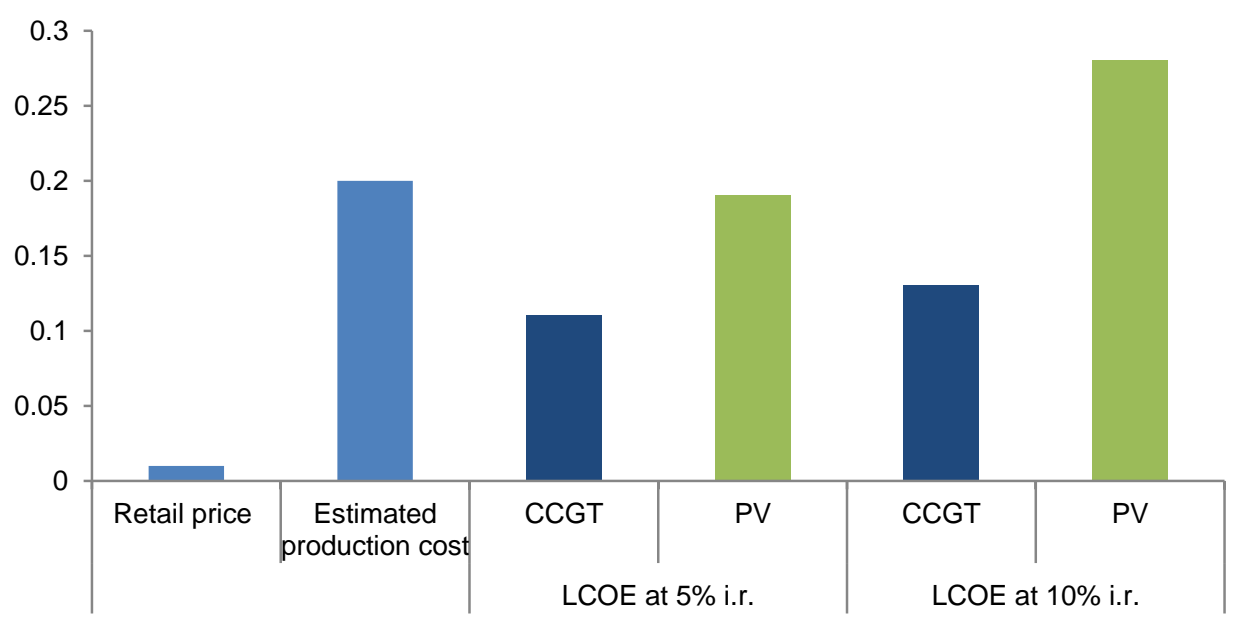

Source: Ramadhan, Hussain and Behbehani (2013); Authors

\footnotetext{
47 Cost estimates kindly supplied by Osamah Alsayegh, Kuwait Institute for Scientific Research.

48 Public-Private Partnership Law No.7/2008. Implementation of the first PPP tender, the Az-Zour North power station Phase 1, is now in progress. The authors thank Osamah Alsayegh for helpful comments.

${ }^{49}$ EIA report, as quoted in 'Kuwaiti oil refineries vulnerable to more power problems', Reuters, 16 February 2014.
} 
In June 2014, Kuwait's utility subsidy bill (including desalinated water) was reported to amount to a vast $\$ 3.5 \mathrm{bn}$, based only on the government's explicit budgetary allocations necessary to ensure the utilities kept running. Kuwait's entire subsidy bill, which includes explicit subsidies on other fuels (natural gas) and, presumably, food, was reported to amount to a massive US $\$ 17.75 \mathrm{bn}$ (KD 5bn). ${ }^{50}$ These fiscal resources have further helped fuel Kuwait's rapidly expanding energy consumption, on the basis of electricity supplied at close-to zero cost. The resultant systematic waste of energy resources - through the absence of consumer consciousness and the lack of incentives for consumers and industrial users to invest in greater energy efficiency - is just one aspect of the various ways in which current pricing practice in the GCC costs the region money.

Nor would the utility have an economic incentive to switch fuel, for it is supplied with low-cost oil and natural gas at prices far below their international market value. The pricing structures reflect the fact that GCC governments do not charge their domestic energy consumers at international shadow prices for their exportable oil and gas, using instead a measure of what they consider their long-run marginal cost of production - typically a historical price which today does not even reflect current and future exploration and production costs, particularly for non-associated natural gas. ${ }^{51}$ The pricing of different fuels relative to each other in order to reflect their full economic cost is unavoidable, however, so that markets receive the right signals over the allocation of these fuels.

From an economic perspective, the most obvious way forward would be the reform of domestic prices for fuels and electricity, to reflect these costs adequately to producers and consumers. Importantly, this step would solve a variety of problems on both the supply and the demand side. On the supply side, interfuel-competition would now be based on true economic cost, potentially shifting incremental investment in new power generation towards a more diversified energy source mix. On the demand side, a critical market distortion in the form of cost-unreflective prices would be removed, leading to an adjustment in domestic energy demand and thus decreasing the need for incremental utility sector investment. Economic deadweight loss would be minimized, while freed-up resources could be distributed via alternative channels, for example in the form of direct cash transfers. ${ }^{52}$

A recent study by the Oxford Institute for Energy Studies argues specifically in the case of Kuwait that:

... spending more on expanding scale while keeping prices artificially low [is] a costly route to alleviating shortages. ${ }^{53}$

This also means that the adoption of renewable energy into the fuel mix of the country, and of the wider region, could turn into a major money drain, or economic sink, if not coupled to an overhaul of prices aimed at setting the right incentives for utilities to make investment choices based on clear economic benefit. ${ }^{54}$

\footnotetext{
50 Trenwith, C. 'Subsidy proposal could deliver \$3.5bn Kuwaiti budget savings', ArabianBusiness.com, 9 June 2014.

${ }^{51}$ Aissaoui, A. (2014) 'Financing MENA Energy Investment: Critical Issues and Challenges', Economic Commentary, Vol. 9 No. 3, March 2014, APICORP Research; Aissaoui, Al (2013) 'Investment in Energy: Looking Beyond Conventional Determinants', Economic Commentary, Vol. 8 No. 11, November 2013, APICORP Research.

${ }^{52}$ Fattouh and El-Katiri (2012); Fattouh, B. and El-Katiri, L. (2013) 'Energy Subsidies in the Middle East and North Africa', Energy Strategy Reviews, 2(1), June 2013, 108-15; Segal, P. (2012) 'How to spend it: Resource wealth and the distribution of resource rents', Energy Policy, Vol. 51, 340-48.

${ }^{53}$ Fattouh, B. and Mahadeva, L. (2014) 'Price Reform in Kuwait’s Electricity and Water Sector', OIES Paper, MEP 9, Oxford Institute for Energy Studies, 36.

${ }^{54}$ For a more detailed discussion of how renewable and other supply-sided energy policy options could be used to promote demand-sided policy reform, see El-Katiri, L. (2014) 'Why renewable energy could be a chance for the GCC economies', Oxford Energy Forum, 96, May 2014, 13-15. Accessible at www.oxfordenergy.org/wpcms/wp-content/uploads/2014/06/OEF96.pdf (retrieved July 2014).
} 
We acknowledge the difficulty of raising fuel and electricity tariffs, given the various ramifications it would entail for the GCC. Nevertheless, such reforms seem increasingly unavoidable in view of the implications of business-as-usual, as outlined above. A recent study, which uses Kuwait as a case study, has furthermore demonstrated that substantial benefit would be gained in Kuwait's context by raising domestic utility prices to their market level; indeed, the authors' model suggests that the fiscal savings associated with an overhaul of utility tariffs would be more than sufficient to compensate consumers on average for the loss, while still leaving a significant surplus that could be allocated to other forms of state spending. ${ }^{55}$

\section{Fiscal support mechanisms: FITs and others}

Both as an alternative to more fundamental price reform, and in combination with other pricing reform steps, the GCC states have the option of using specific fiscal incentive schemes as another policy option to incentivize private investors to invest specifically in renewable energy projects. Fiscal support mechanisms have been widely used in developed markets such as Europe and North America, and also in some emerging economies such as India and China, to support renewablesbased electricity generation. ${ }^{56}$ Important financial support mechanisms include what may be termed 'soft' policy instruments: soft loans and loan guarantees by governments can be a critical tool to help reduce financial investment risk. Used in addition to other financial mechanisms, loan guarantees can significantly increase the attractiveness of an investment to the private investor. ${ }^{57} \mathrm{~A}$ look at the GCC states' policy framework shows that this option has been significantly underexplored by their governments, a view confirmed also by the authors' interviews with stakeholders in several GCC countries. ${ }^{58}$

Feed-in tariffs (FITs) are a popular incentive structure used by governments in many markets to support renewable energy production, and are a likely policy choice for the GCC states as well. FITs guarantee the producer a fixed purchasing price over a period of years (typically 15-20), which helps satisfy lending requirements. The system notably works also where private investors, or privatepublic enterprises, are encouraged to add new projects, as well as in cases of private rooftop selfgeneration. Determination of the FIT level is based on the expected long-run cost of production from a renewables plant (such as solar PV) plus a profit margin for producers that incentivizes them to invest in renewables rather than conventional fuels.

Other than soft policy instruments such as loan guarantees and FITs, the GCC economies are, however, constrained in the variety of fiscal incentives they can offer practically. Typical forms of active support for renewable energy projects in Europe and North America include tax incentives and carbon credit-based systems, such as the European Union's emissions trading certificates. GCC citizens and their corporations are not taxed, however, which leaves the option of tax incentives to foreign private companies investing in the sector. The imposition of a carbon tax, or of a carbonbased credit system, appears similarly unlikely in the context of the GCC states, where the reform of tariffs to reflect costs would arguably need to precede such steps.

\footnotetext{
${ }^{55}$ Fattouh and Mahadeva (2014).

${ }^{56}$ European Environment Agency (2001). Renewable energies: success stories, European Environment Agency Environmental issue report No 27: 29, 61; IEA (2011) Deploying Renewables. Best and Future Policy Practice, Paris: OECD/IEA: 77; Müller, S., Brown, A., and Ölz, S. (2011). Renewable Energy. Policy Considerations for Deploying Renewables, Paris Cedeux: International Energy Agency: 32.

${ }^{57}$ OECD (2013). Renewable Energies in the Middle East and North Africa: Policies to Support Private Investment, OECD Publishing: 54.

${ }^{58}$ Interviews conducted by the authors with power sector stakeholders in Kuwait, the UAE, and Saudi Arabia, May and June 2014.
} 

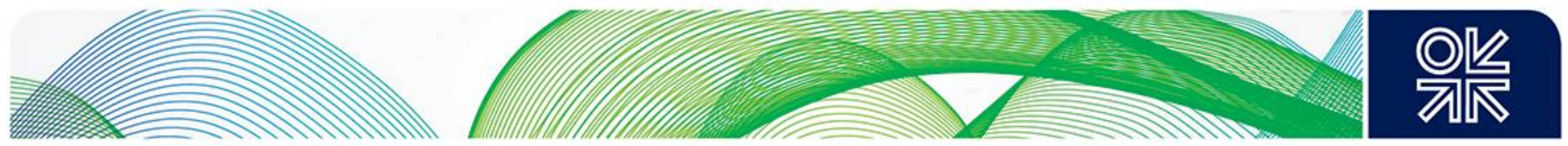

Even FITs bear caveats in the context of the GCC's current utility tariff system: the FIT payable to producers of renewable energy will need to lie many multiples above current domestic retail prices to compensate producers for their costs, rendering FITs an expensive incentive solution. Paying such amounts to private households with rooftop PV panels could eventually prove counterproductive in reducing overall household demand for electricity, given that very small amounts of feed-in solar power would augment the complementary purchasing power (at a retail price $2 \mathrm{fils} / \mathrm{kWh}$ ) for conventionally priced electricity to an absurd proportion. FITs also raise the cost of deadweight loss, for under most FIT schemes, producers face little incentive to reduce costs - indeed, high guaranteed purchase prices may induce utilities to systematically augment costs, thereby leading into unproductive sinks where renewable projects turn into rent-seeking projects.

Indeed, all fiscal incentives effectively introduce an economic distortion into the market in favour of renewable energy. In practice, this introduces a new public cost item, whose cost level can rise enormously depending on the 'success' of the incentive scheme. Countries with successful FIT programmes have in the past had to reduce their FITs in an urge to constrain a cost explosion, a step which, in the GCC context with a non-liberalized utility market, would either involve a highly unpopular rise in tariffs, or a shut-down in uncommercial capacity, particularly as more private sector investors become involved. In the presence of the GCC states' existing cost-unreflective domestic energy price environment, fiscal support mechanisms would introduce a further distortion into an already distorted market, and also create significant potential for dependencies, liabilities, and allegations of corruption, a subject not alien to Kuwait's already overstretched energy sector. ${ }^{59}$

\section{Quotas and Renewables Targets}

Most policy options which offer an alternative to fiscal incentives are a type of quantity-based support mechanism that aims to affect markets more indirectly than is the case with direct fiscal incentives. The problem with any quantity-based policy option in the GCC context remains the fact that such mechanisms were developed in their original format under liberalized markets such as those in Europe, where utilities could achieve regulatory requirements - such as renewables quota production - by passing on investment costs to final customers. This cannot be applied in the GCC context. Since utility prices across the GCC are state-administered and not set by utilities under a competitive market, utilities would be unable to pass on costs to customers; indeed, the most likely option would need to be the creation of new subsidies (to both state-owned utilities and potential future investors) to even allow these utility companies to run. In the case of the region's infant private utility sector, rigid quotas with levels of company compensation which are too low for costs related to renewables programmes, might indeed hamper rather than help foster private sector participation; while inflexible support mechanisms would likely reduce incentives for utilities to reduce costs under renewable energy schemes over time. In both cases, which are realistic scenarios for poorly implemented renewables programmes in the GCC, renewables could become a formidable money-drain.

\footnotetext{
${ }^{59}$ Kuwait ranks 69 out of 177 countries surveyed in Transparency International's 2013 CPI report. The country has seen various high-level investigations, including those initiated by members of the Parliament, into alleged cases. Perhaps the most internationally visible cases have been the multi-year investigation into Shell's contract for services supplied to Kuwait Oil Companyin developing the Northern gas fields during the 2000s, and the 2011 enquiry into what has widely been acclaimed as 'Kuwait's Watergate' involving monetary transfers into several parliamentarians' accounts. Kuwait has made considerable efforts to counteract corruption and money laundering - efforts which have also been taken note of in one of the latest IMF reports on the country. Transparency International (2013) Corruption Perceptions Index 2013. Accessed online at http://cpi.transparency.org/cpi2013/results/ (retrieved July 2014). See also Stack, L. 'Corruption Inquiry Rocks Kuwait', International New York Times, 21 September 2011; MacDonald, F. (2014) 'Kuwait Opposition Returns to Streets for Corruption Rally', Bloomberg, 11 June 2014; International Monetary Fund (2013) Kuwait: Article IV Consultation. IMF Country Report No.13/336, Washington D.C.: International Monetary Fund.
} 

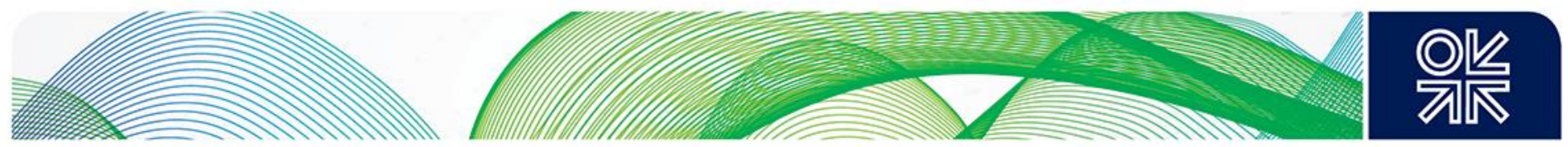

Quota-based systems are a prime mechanism for illustrating this potential dilemma. Renewables quotas are prescriptive policy instruments for increasing the share of renewable energy in the power sector; they stipulate a compulsory share of renewables to power generators, and this needs to be achieved by a certain point in time. A quota differ from a target, which is a vaguer policy objective with little direct relevance to utilities. The benefit of quota systems, in the context of other countries, comes from the more limited interference in market structures than is the case in fiscal incentive schemes such as FITs; under quotas, producers themselves choose what technology to invest in and (most importantly in the European and North American context) the level of pricing. ${ }^{60}$

This latter factor helps explain why quota-based systems will find it more difficult to function as effective policy tools in the GCC; quota-based systems will necessarily lead to loss-making among utilities (which face higher investment costs with no ability to recover these costs on the open market) for as long as GCC governments regulate electricity tariffs. The response by governments under quota-based systems will necessarily need to involve the payment of subsidies to compensate utilities for making losses, feeding back into a vicious circle of fiscal liabilities. The one positive aspect of such a system could be the gradual visualization by citizens of the actual cost of energy to their governments, where subsidies on renewable energy - unlike the implicit opportunity cost of consuming oil domestically rather than exporting it abroad - would form an explicit part of the government's budget. However, in the public eye, this more explicit subsidy on renewables might eventually translate back into a simple questioning of whether renewables offer the region any tangible economic advantage - such thoughts have been expressed to the authors frequently during work on this paper.

Targets for renewable energy may be seen as an even less successful means of raising the share of renewables in the GCC context. An objective rather than a policy per se, a target may be important in devising a government's policy direction - a roadmap in its most basic form but not a replacement for more active policies of promotion such as fiscal incentives or the restructuring of domestic utility markets. All GCC states have, in the past, issued renewables targets, although with inconsistencies (see Table 1). Kuwait, which lags behind most of its GCC neighbours in announcing a clearly defined policy vision for renewable energy, has seen various targets circulating. These typically range from 1 per cent (undefined) renewables-based power generation by 2015 (a share which can safely be assumed to be utterly unrealistic) to 10 per cent (around $7.7 \mathrm{GW}$ ) by 2030 , and 15 per cent by 2030.61

\footnotetext{
${ }^{60} \operatorname{OECD}(2013,63-4)$

${ }^{61}$ In a speech at the 2012 UN Climate Change Conference in Doha, Kuwait's Emir Sheikh Sabah Al-Ahmad Al-Jaber Al-Sabah confirmed Kuwait's goal to generate $1 \%$ of its electricity mix from wind and solar power by 2015 , and up to $15 \%$ by 2030 . At this event, the Emir reaffirmed Kuwait's commitment to renewable energy, which he linked to the ultimate objective of diversifying Kuwait's energy sources. 'HH the Amir delivers speech at UN Climate Change Conference in Doha' Kuwait News Agency, 4 December 2012. For other targets, see REN21/ISEP (2013); 'Kuwait Burns Crude, Turns To Renewables, To Meet Fuel Challenge', MEES, 55:12, 19 March 2012. These targets are attributed to KISR, which has been active in research on renewables in Kuwait for more than 30 years. In a separate UN speech, the Emir of Kuwait Sheikh Jaber Al-Ahmad Al-Sabah suggested a target of $15 \%$ of renewables, though no official policy targets have been released. Frustration over the absence of such clear targets has been reflected in a number of interviews conducted by the authors with key stakeholders in Kuwait City, April and May 2014.
} 
Table 1: Renewable Energy Targets in the GCC States

\begin{tabular}{|l|l|}
\hline Bahrain & $5 \%$ by 2020 \\
\hline Kuwait & $1 \%$ of electricity generation by $2015 ; 10 \%$ by $2020 ; 15 \%$ by 2030 \\
\hline Oman & $10 \%$ of electricity generation by 2020 \\
\hline Qatar & At least $2 \%$ of electricity generation from solar energy sources by 2020 \\
\hline Saudi Arabia & $\begin{array}{l}50 \% \text { of electricity from non-hydrocarbon resources by 2032: } 54 \mathrm{GW} \text { from } \\
\text { renewables (of which: } 41 \mathrm{GW} \text { from PV and CSP, } 9 \mathrm{GW} \text { wind, 3GW waste-to- } \\
\text { energy, } 1 \mathrm{GW} \text { geothermal), } 17.6 \mathrm{GW} \text { from nuclear }\end{array}$ \\
\hline UAE & $\begin{array}{l}\text { Dubai: } 5 \% \text { of electricity by } 2030 ; \text { Abu Dhabi: } 7 \% \text { of electricity generation } \\
\text { capacity by } 2020\end{array}$ \\
\hline
\end{tabular}

Source: REN21/ISEP (2013). Global Renewable Futures Report 2013. Available online at www.ren21.net (retrieved November 2013); Authors; Kuwait News Agency

It remains unclear how some of this capacity is intended to be achieved, given the marked absence of any known investment projects, or indeed of supporting policies to promote renewable energy in countries such as Kuwait, Bahrain, and even Saudi Arabia. Kuwait expects that between the end of 2015 and the beginning of 2016, Shagaya Renewable Energy Power Plant (Phase-1) will be commissioned, with total installed capacity of $70 \mathrm{MW}$ (60 MW solar technologies + $10 \mathrm{MW}$ wind). It is 100 per cent government investment. The purpose of Phase- 1 is not purely power production it is rather:

(i) a demonstration to assess the technical and economic performance of renewable technologies,

(ii) supporting the development of regulatory framework with respect to power purchasing and power dispatching, etc., and

(iii) providing private investors with performance data and information to reduce their risk in the development of Shagaya phases 2 and 3.62

Generally, the difficulty of moving from targets to actual renewables deployment at commercial scale reflects weaknesses in domestic planning which have been witnessed in other parts of the GCC, for instance in Abu Dhabi during the late 2000s. While the country now ranks among the premier Middle East investors in renewable energy, a 2012 study looking back at the 2000s criticizes the mismatch between government aims and strategy, arguing:

In the absence of a comprehensive planning document, Abu Dhabi has made several announcements that can be interpreted as parts of a new strategy that includes the promotion of renewable energies, such as the 7 per cent renewable energy goal ..., the announcement to launch a solar rooftop programme, and the introduction of a smart metering system ... as a first step into an innovative demand side management system in 2011. Thus, while elements of a comprehensive strategy have been released, the document as a whole is still missing in spite of its public announcement in early 2009. This is also the case for details about funding schemes, tax deductions, and the height of premiums for renewable electricity or other tangible data that are vital for any substantial business plan. ${ }^{63}$

A 2013 OECD report confirms this observation on a more regional basis, saying:

Some MENA governments are setting targets for renewable energy power generation. However, compared to the practice in most OECD countries, these targets are non-binding. Moreover, even the countries that do have targets are experiencing delays in attracting sufficient interest in renewable energy projects. The

\footnotetext{
62 Personal communication by the authors with Osamah Alsayegh, Kuwait Institute for Scientific Research.

${ }^{63}$ Kumetat $(2012,204-5)$.
} 
unattractiveness of the local business climate, political choices that favor cheap fossil fuels and a general lack of transparency in the support mechanisms available for investors often account for delays. The underlying challenges include insufficient capacity and training and a lack of transparency. Beyond providing attractive incentives, a lack of state guarantees decreases the attraction of all long-term infrastructure projects in the MENA region. 64

Targeting alone will thus not be enough; renewable energy in Kuwait, as in the wider region, will need to be promoted by effective policies that address, primarily, the cost - the economic disadvantage that is faced by renewables projects, and not only in the GCC.

Kuwait also lacks a wider energy vision which, despite similar caveats to policy goals at a wider energy sector level, could help contextualize the role the government sees for different energy sources over the coming years. A number of other GCC states have already issued long-term visions, albeit with varying detail and - importantly - explicit strategy steps to be taken; 65 Saudi Arabia has, for instance, beside its regular 5-year development plans, a Long-Term Strategy (with reach up to 2024), which includes aims to diversify the economy and development of the country's oil and gas sectors. ${ }^{66}$ While alternative sources of energy are lamentably missing, the document is an important starting point for similar policy plans in the future. The UAE's Vision $2021^{67}$ and Qatar's National Vision $2030^{68}$ offer some more inclusive strategies that already specifically consider 'sustainable' energy options and the importance of climate change mitigation as important elements in their countries' future policy agendas.

\section{Conclusions}

Renewable energy still has a long way to go in the GCC. Today, however, more than at any other time in the history of the GCC states, the focus on energy alternatives may indeed begin to shift away from the sole reliance on oil and natural gas, towards a portfolio of energy options which includes renewable energy. Renewable energy, primarily solar power owing to plentiful resources on the Arabian Peninsula, will likely play a part in this new energy future, despite the possibility of sharp differences between the pace and extent of deployment between different countries within the region. Saudi Arabia and the UAE have moved ahead with some of the Middle East's most ambitious renewable energy plans, whose eventual manifestation has yet to be seen as the two countries need to re-focus away from prestige projects towards marketable long-term solutions, to encourage a more systematic take-up of alternative energy sources.

It is also important for the GCC economies to reconsider their historical path; rising energy consumption, the growing opportunity cost of burning exportable oil domestically, and the prospect of diverting increasing shares of their oil production to their domestic markets holds a whole set of different challenges which await the GCC economies in the case of business-as-usual. The choice is more obvious in the short-term in the case of countries that still rely on oil-fired power generation (that is Saudi Arabia, Kuwait, and the UAE) since the cost-effectiveness of solar power to oil is most obvious in the current international pricing climate and is likely to remain so in the foreseeable future.

\footnotetext{
${ }^{64} \operatorname{OECD}(2013,13)$.

${ }^{65}$ For a discussion, see Hvidt, M. (2012) 'Planning for Development in the GCC States: A Content Analysis of Current

Development Plans', Journal of Arabian Studies, 2:2 (2012), 198-207.

${ }^{66}$ Al-istratijiyyah ba'adiyyah al-maddah l-i-l-iqtisad al-watani (in Arabic), Saudi Ministry of Economy and Planning. Downloaded from

http://www.mep.gov.sa/themes/GoldenCarpet/index.jsp;jsessionid=A6176012081D68601A6886968C7F9591.alfa?event=Switc hLanguage\&Code=AR\#1405269673497 (retrieved June 2014).

${ }^{67}$ Ru'iyyah dawlah al-imarat 2021 (in Arabic, also available in English), United Arab Emirates, downloaded from http://www.vision2021.ae/ar/home-page.html (retrieved June 2014).

${ }_{68}^{68}$ Ru'iyyah Qatar Al-Wataniyah 2030. General Secretariat for Development and Planning, Qatar. Downloaded from http://www.gsdp.gov.qa/www1 docs/QNV2030 Arabic v2.pdf (retrieved June 2014).
} 

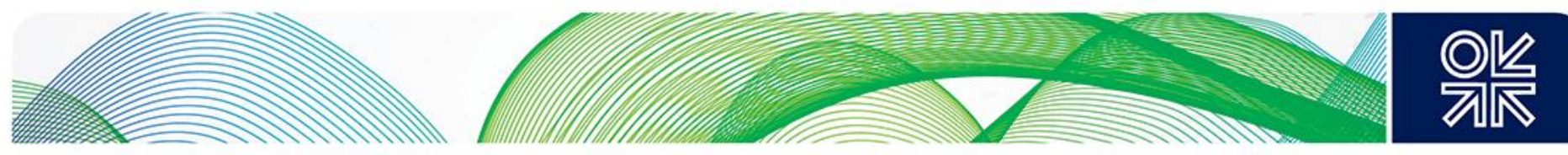

But also, in the case of the region's growing natural gas importers (most importantly Kuwait) rising gas imports may render renewable energy increasingly cost-competitive.

But there is also a long-term scenario, which provides ample reason for the GCC states to consider investment in alternative energy options now, whether or not they find the economic argument overwhelmingly convincing. The recent case of Egypt (while allowing for some important differences between Egypt and the GCC economies in terms of economic decision-making and the time horizon for existing known hydrocarbon reserves) illustrates the enormous economic difficulties associated with decade-long business-as-usual policies in the domestic energy sector. Egypt has already experienced the plight of being an oil and gas exporter that has become a net importer of energy within less than a decade - and against the expectations of a mere ten years ago. While similar scenarios may yet be remote from the planning horizon of many Gulf policymakers today, a prudent look at the allocation of domestic resources suggests that the GCC economies can, over the long term, gain from the deployment of alternative energy technologies.

None of these considerations includes the potential additional benefits that renewables would entail for the region, most importantly in the areas of environmental mitigation of the GCC states' high per capita fossil fuel use, and through new industrial diversification options into new energy industries.

We have argued above that among the most significant challenges facing the GCC states in deploying renewables systematically will likely be the creation of market-based mechanisms that allow utility providers to pick up renewables as a cost-effective fuel choice over the long term. Most importantly, this will involve a restructuring of energy and utility pricing, which forms a critical part of providing visible economic incentives for the use of renewables over domestically produced fossil fuels. In the absence of more market-based mechanisms, renewables could, however, turn into an expensive investment for the GCC nations, moving economic distortions and deadweight loss from one energy source to another. For this reason, it is necessary for policymakers to combine supplyside energy solutions with demand-side schemes to create policies that not only help the GCC economies manage their domestic demand, but that also facilitate the market-based take-up of supply-sided solutions beyond government take. 


\section{Bibliography}

Aissaoui, A. (2013). 'Investment in Energy: Looking Beyond Conventional Determinants', Economic Commentary, Vol. 8 No. 11, November 2013, APICORP Research.

Aissaoui, A. (2014). 'Financing MENA Energy Investment: Critical Issues and Challenges', Economic Commentary, Vol. 9 No. 3, March 2014, APICORP Research.

Al-Enezi, F.Q., Sykulski, J. K., and Ahmed, N.A. (2011). 'Visibility and Potential of Solar Energy on Horizontal Surface at Kuwait Area', Energy Procedia, 12 (2011) 862-72.

Al Moneef (2006). The Contribution of the Oil Sector to Arab Economic Development, OFID Pamphlet Series No. 34, Vienna: OPEC Fund for International Development.

Al-Harbi, M. (2013). 'Assessment of Air Quality in two Different Urban Localities', International Journal of Environmental Resources, 8(1), 15-26,Winter 2014.

Al-Hasan, Y.A., Ghoneim, A.A., and Abdullah, A.H. (2004). 'Optimizing electrical load pattern in Kuwait using grid connected photovoltaic systems', Energy Conversion and Management, 45 (2004). 483-94.

Al-Nassar, W., Alhajraf, S., Al-Enizi, A. and Al-Awadhi, L. (2005). 'Potential wind power generation in the State of Kuwait', Renewable Energy 30 (2005) 2149-61.

Al-Sabah, Y. S. F. (1980). The Oil Economy of Kuwait, London: Kegan Paul International.

Al-Yahya, M. A. (1993). Kuwait: Fall and Rebirth, London: Kegan Paul International.

Alotaibi, S (2011). 'Energy consumption in Kuwait: Prospects and future approaches', Energy Policy, 39 (2011) 637-43.

Astorri, F. (2013). 'Qatar air pollution six times over limit - study', ArabianBusiness.com, 22 January 2013.

Bachellerie, I.J. (2012). Renewable Energy in the GCC Countries: Resources, Potential and Prospects, Gulf Research Centre.

Bachellerie, I.J. (2013). 'Sustainability and Competitiveness: A Pragmatic Approach to Solar Energy Transition in the GCC Countries', GRC Gulf Paper, Gulf Research Centre.

BNEF (2011). The Sun Sets on Oil for Gulf Power Generation. White Paper, Bloomberg New Energy Finance, 19 January 2011.

Brown, A., Mueller, S., and Dobrotkova, Z. (2011). 'Renewable Energy Markets and Prospects by Technology', Information Paper, International Energy Agency, Paris: IEA.

Crystal, J. (1995). Oil and Politics in the Gulf: Rulers and Merchants in Kuwait and Qatar, Cambridge: Cambridge University Press.

Darwish, M.A., Al-Awadhi, F.M., and Darwish, A.M. (2008). 'Energy and water in Kuwait Part I. A sustainability view point', Desalination, 225 (2008) 341-55.

DLR (2005). Concentrating Solar Power for the Mediterranean Region, A study commissioned by Federal Ministry for the Environment, Nature Conservation and Nuclear Safety Germany, Stuttgart: Deutsches Zentrum für Luft- und Raumfahrt e.V.

EIA (2013). Bahrain Country Analysis Brief, Accessed from www.eia.gov/countries/countrydata.cfm?fips=ba (accessed July 2014). 
El-Husseini, I., Fayad, W., El Sayed, T., and Zywietz, D. (2009). 'A New Source of Power. The Potential for Renewable Energy in the MENA Region', Booz \& Co Perspective, available at www.booz.com/media/file/A New Source of Power.pdf (retrieved November 2013).

El-Katiri, L. (2012) 'The GCC and the Nuclear Question' Oxford Energy Comment, Oxford Institute for Energy Studies.

El-Katiri (2013). 'Energy Sustainability in the Gulf States: The Why and the How', OIES Research Paper, MEP 4, Oxford Institute for Energy Studies. Accessible at www.oxfordenergy.org/wpcms/wpcontent/uploads/2013/03/MEP 4.pdf (retrieved July 2014).

El-Katiri, L. (2014). 'A Roadmap for Renewable Energy in the Middle East and North Africa', OIES Paper, MEP 6, Oxford Institute for Energy Studies. Accessible at www.oxfordenergy.org/wpcms/wpcontent/uploads/2014/01/MEP-6.pdf (retrieved July 2014).

El-Katiri, L. (2014). 'Why renewable energy could be a chance for the GCC economies', Oxford Energy Forum, 96, May 2014, 13-15. Accessible at www.oxfordenergy.org/wpcms/wpcontent/uploads/2014/06/OEF-96.pdf (retrieved July 2014).

European Environment Agency (2001). Renewable energies: success stories, European Environment Agency Environmental issue report No 27. Downloaded from www.eea.europa.eu/publications/environmental issue report 200127 (retrieved July 2014).

Fattouh, B. and El-Katiri, L. (2013). 'Energy Subsidies in the Middle East and North Africa' (with B. Fattouh), Energy Strategy Reviews, 2(1), June 2013, 108-15.

Fattouh, B. and El-Katiri, L. (2012). 'Energy and Arab Economic Development', Arab Human Development Report Research Paper Series, United Nations Development Programme. Available at www.arab-hdr.org/publications/other/ahdrps/ENGFattouhKatiriV2.pdf (retrieved January 2014).

Fattouh, B. and Mahadeva, L. (2014). 'Price Reform in Kuwait's Electricity and Water Sector', OIES Paper, MEP 9, Oxford Institute for Energy Studies. Accessible at www.oxfordenergy.org/wpcms/wpcontent/uploads/2014/04/MEP-9.pdf (retrieved July 2014).

Ghaddar, N.K., Shihab, M., and Bdeit, F. (1997). 'Modelling and Simulation of Solar Absorption System Performance in Beirut', Renewable Energy, 10:4, 539-58.

Ghoneim, A.A., Al-Hasan, A.Y., Abdullah, A. H. (2002) 'Economic analysis of photovoltaic-powered solar domestic hot water systems in Kuwait' Renewable Energy 25 (2002) 81-100.

Griffiths, S. (2014). 'Masdar City: "City of Possibilities"', Oxford Energy Forum, 96, May 2014, 18-21. Accessible at www.oxfordenergy.org/wpcms/wp-content/uploads/2014/06/OEF-96.pdf (retrieved July 2014).

Hammerl, L. (2007). 'Saudi Arabia's Accession to the WTI: Opportunities and Predicaments', Unpublished B.A. dissertation, University of Exeter.

Hvidt, M. (2012). 'Planning for Development in the GCC States: A Content Analysis of Current Development Plans', Journal of Arabian Studies, 2:2 (2012), 198-207.

IEA (2011). Deploying Renewables. Best and Future Policy Practice, Paris: OECD/IEA.

ILO (2008). 'Employment and labour market implications of climate change', GB.303/ESP/4, Geneva, November 2008.

International Monetary Fund (2013). Kuwait: Article IV Consultation, IMF Country Report No.13/336, Washington D.C.: International Monetary Fund. 
Kamrava, M. (2012). The Nuclear Question in the Middle East, New York: Columbia University Press.

Kumetat, D. (2012). Managing the Transition: An Analysis of Renewable Energy Policies in ResourceRich Arab States with a Comparative Focus on the United Arab Emirates and Algeria, Unpublished $\mathrm{PhD}$ thesis, available online at http://etheses.Ise.ac.uk/623/1/Kumetat Managing transition.pdf (retrieved November 2013).

Kuwait Institute for Scientific Research (KISR, 2008). Scientific Report 2006-2008, viii, as quoted by Bachellerie, I.J. (2012).

Luciani, G. (2012). 'The Role of Nuclear Energy in Gulf States' Economic Development', in: Kamrava, M. (2012).

Lund, P.D. (2009). 'Effects of energy policies on industry expansion in renewable energy', Renewable Energy, 34, 53-64.

Luomi, M. (2014). 'Mainstreaming Climate Policies in the Gulf Cooperation Council States', OIES Research Paper MEP 7, Oxford Institute for Energy Studies. Accessible at www.oxfordenergy.org/wpcms/wp-content/uploads/2014/02/MEP-7.pdf (retrieved July 2014).

Luomi, M. (2011). 'Gulf of Interest: Why Oil Still Dominates Middle Eastern Climate Politics', Journal of Arabian Studies, 1:2, 249-66.

Marktanner, M. and Salman, L. (2011). 'Economic and geopolitical dimensions of renewable vs. nuclear energy in North Africa', Energy Policy, 39 (2011) 4479-89.

Meltzer, J., Hultman, N., and Langley, C. (2014). Low-Carbon Energy Transitions in Qatar and the Gulf Cooperation Council Region, Washington D.C.: The Brookings Institution.

Mills (2012). Sunrise in the Desert. Solar Becomes Commercially Viable in the MENA, Emirates Solar Industry Association (ESIA).

Mills, R. (2014). 'Climate Change and CCS in the GCC', Oxford Energy Forum, 96, May 2014, 38-41. Accessible at www.oxfordenergy.org/wpcms/wp-content/uploads/2014/06/OEF-96.pdf (retrieved July 2014).

Müller, S., Brown, A., and Ölz, S. (2011). Renewable Energy. Policy Considerations for Deploying Renewables, Paris Cedeux: International Energy Agency: 32.

OECD (2011). Towards Green Growth, (Organisation for Economic Co-operation and Development), OECD, Paris, http://www.oecd.org/greengrowth/48224539.pdf. (retrieved November 2013).

OECD (2013). Renewable Energies in the Middle East and North Africa: Policies to Support Private Investment, OECD Publishing.

Patlitzianas, K.D., Doukas, H., and Psarras, J. (2006). 'Enhancing renewable energy in the Arab States of the Gulf: Constraints \& efforts', Energy Policy, 34, 3719-26.

Ramadhan, M. and Naseeb, A. (2011). 'The cost benefit analysis of implementing photovoltaic solar system in the state of Kuwait', Renewable Energy, 36 (2011) 1272-6.

Ramadhan, M., Hussain, A., and Behbehani, D. (2013). 'The Prospect of Solar Energy in the Development of Power Stations in the State of Kuwait', Journal of Renewable Energy, Volume 2013.

Reiche, D. (2010). 'Renewable Energy Policies in the Gulf countries: A case study of the carbonneutral "Masdar City" in Abu Dhabi', Energy Policy, 38 (2010) 378-82. 
REN21/ISEP (2013). Global Renewable Futures Report 2013. (Paris: REN21) Available online at www.ren21.net (retrieved November 2013).

Russell, J.A. (2011). 'The Persian Gulf: Bahrain, Iran, Iraq, Kuwait, Qatar, Saudi Arabia, the United Arab Emirates, and Oman', in Daniel Moran (ed.), Climate Change \& National Security, Washington D.C.: Georgetown University Press, 2011, 163-76.

Segal, P. (2012). 'How to spend it: Resource wealth and the distribution of resource rents', Energy Policy, Vol. 51, 340-48.

UNEP (2008). Green Jobs: Towards Decent Work in a Sustainable, Low-Carbon World, United Nations Environment Programme, Nairobi.

World Trade Organization (2011). Trade Policy Review. Report by the Kingdom of Saudi Arabia, WT/TPR/G/256, downloaded from www.wto.org/english/tratop e/tpr e/g256 e.doc (accessed July 2014).

\section{National government strategies}

Al-istratijiyyah ba'adiyyah al-maddah l-i-l-iqtisad al-watani (in Arabic), Saudi Ministry of Economy and Planning. Downloaded from

www.mep.gov.sa/themes/GoldenCarpet/index.jsp;jsessionid=A6176012081D68601A6886968C7F959 1.alfa?event=SwitchLanguage\&Code=AR\#1405269673497 (retrieved June 2014).

Ru'iyyah dawlah al-imarat 2021 (in Arabic, also available in English), United Arab Emirates, downloaded from http://www.vision2021.ae/ar (retrieved June 2014).

Ru'iyyah Qatar Al-Wataniyah 2030. General Secretariat for Development and Planning, Qatar. Downloaded from www.gsdp.gov.qa/www1 docs/QNV2030 Arabic v2.pdf (retrieved June 2014).

\section{Newspaper and trade journal articles}

'Global air pollution: what is the most polluted country and city in the world?', The Guardian, 26 September 2011.

'HH the Amir delivers speech at UN Climate Change Conference in Doha', Kuwait News Agency, 4 December 2012.

'Kuwait Burns Crude, Turns To Renewables, To Meet Fuel Challenge', Middle East Economic Survey, 55:12, 19 March 2012.

'Kuwait Ponders Long-Term Power Fuel Supply Options: MEES Analysis', Middle East Economic Survey, 55 56:24, 14 June 2013.

'UAE 3rd in concentrated solar power capacity', Khaleej Times, 4 June 2014.

'Kuwait Burns Crude, Turns To Renewables, To Meet Fuel Challenge', MEES, 55:12, 19 March 2012. 'Kuwaiti oil refineries vulnerable to more power problems', Reuters, 16 February 2014.

MacDonald, F. (2014). 'Kuwait Opposition Returns to Streets for Corruption Rally', Bloomberg, 11 June 2014.

Stack, L. 'Corruption Inquiry Rocks Kuwait', International New York Times, 21 September 2011.

Trenwith, C. 'Subsidy proposal could deliver \$3.5bn Kuwaiti budget savings', ArabianBusiness.com, 9 June 2014. 


\section{Data \& Statistics}

AUPTDE (2013). 'Al-ta3rifat al-kahraba'iyyah fi-I watan al-a3rabi', Arab Union of Electricity Producers, June 2012.

EIA (2014). International Energy Statistics. Available at www.eia.gov/cfapps/ipdbproject/IEDIndex3.cfm (accessed July 2014).

IEA (International Energy Agency) data, available at www.iea.org/sankey/\#?c=Kuwait\&s=Balance (accessed July 2014).

International Energy Agency (2014). World Energy Outlook 2014, Paris Cedeux: International Energy Agency.

Transparency International (2013). Corruption Perceptions Index 2013. Accessed online at http://cpi.transparency.org/cpi2013/results/ (retrieved July 2014).

UNEP (2007). Air Quality and Atmospheric Pollution In the Arab Region, Economic and Social Commission for Western Asia/League of Arab States, available at www.un.org/esa/sustdev/csd/csd14/escwaRIM bp1.pdf (retrieved July 2014).

World Bank (2014) World Development Indicators. Accessed online at http://data.worldbank.org/datacatalog/world-development-indicators (retrieved July 2014).

World Health Organization (2014). Ambient Air Pollution Database, May 2014. Available at www.who.int/phe/health topics/outdoorair/databases/cities/en/ (retrieved July 2014). 